\title{
Coexistence of rice production and threatened plant species: testing Marsilea quadrifolia L. in N-Italy
}

\author{
Anna Corli ${ }^{1}$ - Simone Orsenigo ${ }^{1}$ (D) $\cdot$ Renato Gerdol ${ }^{2} \cdot$ Stefano Bocchi ${ }^{3} \cdot$ Alfons P. Smolders $^{4} \cdot$ Lisa Brancaleoni $^{2}$. \\ Maria Teresa Caffi ${ }^{1} \cdot$ Thomas Abeli $^{5} \cdot$ Graziano Rossi $^{1}$
}

Received: 24 July 2020 / Revised: 28 December 2020 / Accepted: 8 January 2021 / Published online: 29 January 2021

(C) The Author(s) 2021

\begin{abstract}
In the past, the aquatic pteridophyte Marsilea quadrifolia $\mathrm{L}$. was considered as a weed in paddy fields of southern Europe. The systematic use of herbicides as a crucial component of intensive agronomic approach has led to a dramatic decline in M. quadrifolia populations in European countries, mostly in the Mediterranean area. However, the introduction in recent years of sustainable rice cultivation practices has allowed partial recovery. We present here the results of a research aimed at analyzing the effects of farming typologies in respect to M. quadrifolia growth in the Po Valley area. After having transplanted M. quadrifolia swards in rice fields belonging to different farming systems, we monitored its growth and diffusion. Our results showed that $M$. quadrifolia has higher vegetative performance in organic farms, even though it can survive in conventional fields with reduced herbicide supply. Differences in water chemistry have limited effects on M. quadrifolia performance, because of its wide ecological amplitude. The shady conditions provided by rice canopy create micro-habitats suitable for M. quadrifolia growth. Cultivating M. quadrifolia in organic rice farms represents an important opportunity for preserving this endangered species in areas of intensive agriculture. This can, meanwhile, represent a valid opportunity to combine nature conservation and productivity offering a new possible income for farmers.
\end{abstract}

Keywords Agroecology $\cdot$ Biodiversity $\cdot$ EU common agricultural policy $\cdot$ Plant conservation $\cdot$ Reintroduction

Supplementary Information The online version of this article (https://doi.org/10.1007/s10333-021-00840-z) contains supplementary material, which is available to authorized users.

Simone Orsenigo

simone.orsenigo@unipv.it

1 Department of Earth and Environmental Sciences, University of Pavia, via S. Epifanio, 14, 27100 Pavia, Italy

2 Department of Life Sciences and Biotechnology, University of Ferrara, Corso Ercole I d'Este 32, 44121 Ferrara, Italy

3 Department of Environmental Science and Policy, University of Milan, Via Celoria 2, 20133 Milan, Italy

4 Department of Aquatic Ecology and Environmental Biology, Institute for Water and Wetland Research, and B-WARE Research Centre, Radboud University, Toernooiveld 1, 6525 ED Nijmegen, The Netherlands

5 Department of Science, University of Roma Tre, Viale Guglielmo Marconi 446, 00146 Rome, Italy

\section{Introduction}

Many plant and animal species associated with agricultural environments experienced severe population declines during the last century (Meyer et al. 2013; Arbeiter et al. 2018). Among these, four leaf clover [Marsilea quadrifolia L. (Marsileaceae)] can be considered as an emblematic species. This aquatic pteridophyte grows in slightly eutrophic waters, including river oxbows, temporary ponds and rice paddies (Gentili et al. 2010). In the past, for a long period, it was considered as a weed in paddy fields of southern Europe (Viggiani et al. 2003). European rice farmers, with the so-called Green Revolution starting from 1950s, modified rice agrotechniques by introducing new practices like mechanization, use of chemicals and simplified rotation (Ferrero and Vidotto 2010; Hill et al. 1991). This led to a drastic decline of Marsilea quadrifolia that is now considered in unfavorable conservation status in most European countries (EEA 2019), including Italy (Rossi et al. 2016). Concerns about its conservation status led to the inclusion of M. quadrifolia in Annexes II and IV of 
the EU Directive 92/43/EC "Habitats" and in the Annex I of Bern Convention, the primary legal instruments driving species protection in Europe (Online Resource 1). Species and habitats listed in the Directive 92/43/EC require a strict protection and their long-term survival should be applied in the Natura 2000 network, a system of areas for the conservation of the flora and fauna stretching across all EU countries, through the establishment of Special Areas of Conservation (SAC). However, in highly anthropized regions SAC are in contact or included in areas of intensive agriculture.

In Po Valley (Northern Italy), a region hosting more than $50 \%$ of the European rice production area with total production of 1,512,228 tons per year (Kraehmer et al. 2017; Enterisi 2018), new spontaneous occurrences of M. quadrifolia were recently recorded in some rice farms. These new records are likely due to improved environmental conditions related to organic or low-input farming practices (Hazra et al. 2018) or changed management practices in conventional farms, as planned by the European Directive on the sustainable use of herbicides (Directive 2009/128/EC; Online Resource 1). Despite improved environmental conditions in rice farms, natural spreading of $M$. quadrifolia to pre-green revolution levels may be jeopardized by landscape fragmentation and limited to farms adopting agroecological principles and practices.

Reintroduction of M. quadrifolia in agricultural areas may represent an opportunity to improve the conservation status of the species but may create conflicts with farmers. Attempts to recover viable populations have been conducted in rice fields of the Ebro Delta Natural Park, Spain (Estrelles et al. 2001).

The EU Common Agricultural Policy (CAP) provides specific funds from the Rural Development Programme (Online Resource 1) for farmers willing to contribute to the conservation of habitats and species (Paracchini et al. 2015). Although these measures are considered not yet sufficient (Pe'er et al. 2020), in some cases they are very effective because they transform potential conflicts between nature conservation and productivity into new income chances for farmers.

With the aim to stimulate the adoption of specific measures for the conservation of M. quadrifolia [and other species from similar habitats like Isoetes malinverniana Ces. $\&$ De Not. and Lindernia procumbens (Krocker) Philcox] in areas of intense agriculture, we explored the possibility of successfully growing $M$. quadrifolia 'on farm' in rice paddies. Specifically, we aimed to answer the following questions: (i) can environmental conditions in rice farms promote land sharing between agriculture activity and Marsilea quadrifolia? (ii) Is the performance of $M$. quadrifolia affected by the farming system typology? (iii) How M. quadrifolia is affected by the presence of rice plants? Answering those questions can help to set up and apply a conservation plan for M. quadrifolia in southern Europe.

\section{Materials and methods}

\section{Farm description and cultivation techniques}

We cultivated M. quadrifolia in four wet rice farms with differing farming systems in the province of Pavia (Po Valley, N-Italy): two organic farms, one conventional farm and a farm in transition from conventional to organic farming (hereafter called 'transitional'). According to the Council Regulation (EC) n. 834/2007 on organic production and labelling of organic products and following updates (Online Resource 1) and its transposition in the Italian Law (last update Ministerial Decree n. 3286/2016), organic farms are recognized and distinguished from conventional farms because they mainly adopt fertilization with natural fertilizer of animal origin or with organic matter and maintain/ enhance soil fertility and biological activity through multiannual crop rotation. More in general, organic agriculture involves complex systems, regulated by long-term biological processes (e.g., humus formation) and non-linear effects, then the effectiveness of an agricultural practice is site- and time- specific. On the other hand, conventional agriculture involves standardized techniques, applied in simplified and specialized cropping systems managed with a short-term approach and based on the fast action of external inputs (Duru et al. 2015; Orlando et al. 2020).Transitional farms are those that have been converted from conventional managing system but are still not recognized as organic farms. During the experimental cultivation of M. quadrifolia, farmers managed the fields with normal agro-techniques (as they usually do), including application of fertilizers and herbicides in the conventional farm. Herbicide treatments varied between years, depending on weeds (Online Resource 2). The rice cultivars were Ronaldo in the organic farms, Baldo in the transitional one and Selenio in the conventional farm; the slightly differences between the three varieties did not affect significantly the performance of Marsilea quadrifolia.

\section{Experimental cultivation of $M$. quadrifolia}

The experimental cultivation of M. quadrifolia was conducted in 2017 in eight rice paddies, two in each farm, whereas in 2018 the cultivation was restricted to six rice paddies. Six $20 \times 20 \mathrm{~cm}$ potted swards of $M$. quadrifolia were placed along a transect in each paddy field. Before the swards were placed in the fields, the shoots were cut to a height of ca. $1 \mathrm{~cm}$ to standardize the initial biomass. In 2017, M. quadrifolia swards were placed in early July after the first (pre-sowing) and the second (post-emergence) herbicide 
treatments in the conventional farm had been supplied in the conventional farm. In 2018, the swards were again placed in the field at the end of May just after rice sowing, so that M. quadrifolia was subjected to the whole spectrum of herbicide treatments. In 2018, once swards were placed in the field, rice was removed to create a $1 \mathrm{~m}^{2}$ open area all around the swards, to evaluate the micro-environmental conditions that can affect growth of M. quadrifolia in paddy fields (sunny vs shaded). As M. quadrifolia spread well beyond the border of open areas under the rice canopy, the growth performance of $M$. quadrifolia was evaluated both in the open areas and under the rice canopy.

\section{Data collection and statistical analyses}

Total biomass of M. quadrifolia was collected at the end of September in both years in a 3-m radius circular area around each sward, oven-dried at $100{ }^{\circ} \mathrm{C}$ for $24 \mathrm{~h}$ and weighed in the laboratories of the University of Pavia. One soil sample and two water samples were collected in 2017 in each paddy field at the time of swards placement and analyzed by the Vassanelli Food and Drink analysis s.r.l., Bussolengo (Italy) and at the University of Nijmegen, respectively (Online Resource 3). In 2018, temperature and irradiance were recorded at 15 -min intervals by data loggers (Hobo, Onset Bourne, MA, USA) during the week preceding rice harvest (13-20 September) in open areas and under rice canopy. The data loggers were placed 1-m above ground. At the beginning of September, chlorophyll fluorescence $\left(F_{v} F_{m}{ }^{-1}\right)$ was determined in the field on M. quadrifolia with a modulated fluorometer (Opti Sciences, OS1-FL, Tyngsboro, MA, USA) both in open areas and under rice canopy. Leaf samples of M. quadrifolia were collected and used to determine spectrophotometrically (UV-Vis spectrophotometer, Pharmacia Biotech Ultrospec, 2000) the concentration of chlorophyll $a$, chlorophyll $b$ and total carotenoids using the extinction coefficients of Lichtenthaler (1987). Since M. quadrifolia did not survive herbicide application in the conventional farm, only the organic farms and the transitional farm were considered. Data on biomass were log-transformed and statistically analyzed by one-way ANOVAs with farming system as explanatory variable and swards and fields as covariates. Comparison between farming systems was performed with Fisher's LSD post hoc test. Data on temperature, irradiance, chlorophyll fluorescence, pigment concentrations and pigment ratios were statistically analyzed by one-way ANOVAs with micro-environment (sunny vs shaded) as the explanatory variable. Stepwise multiple discriminant analysis was performed both for water and soil chemistry in relation to farming system. The statistical analyses were carried out with R v3.6.1 (R Core Team 2019) and STATISTICA 7.0 (StatSoft Inc., Tulsa, OK, USA).

\section{Results}

\section{Plant biomass, water chemistry and soil chemistry}

Total biomass of M. quadrifolia was highest in organic farms both in 2017 and in 2018 (Fig. 1). The ANOVAs revealed no significant differences in plant biomass among farming systems in $2017\left(F_{2,43}=3.12 ; p=0.054\right)$, whereas differences were significant in $2018\left(F_{2,31}=32.54 ; p<0.001\right)$. It is noteworthy the effects of covariates were not significantly different except in $2017\left(F_{1,43}=8.11, p=0.007\right)$. In 2018, M. quadrifolia did not survive in the conventional farm.

Discriminant analysis revealed differences among farming systems in terms of water chemistry $\left(F_{1,14}=8.81\right.$, $p<0.001$; Wilk's $\Lambda=0.010$ ). Water chemistry in the transitional farm differed strongly from both the conventional farm and the organic farms which mirrored in a sharp separation of the two groups across the first discriminant axis (Fig. 2). Indeed, water in the transitional farm was richer in dissolved ions, especially $\mathrm{HCO}_{3}{ }^{-}, \mathrm{NO}_{3}{ }^{-}$and $\mathrm{SO}_{4}{ }^{-2}$, and thus presented higher electrical conductivity (Online Resource 3 ). Conversely, soil chemistry did not differ significantly among farming systems $\left(F_{10,2}=1.11, p<0.56\right.$; Wilk's $\Lambda=0.023$; Online Resource 3).

\section{Micro-environment and photosynthetic efficiency}

Temperature differed significantly between micro-environments $\left(F_{1,22}=33.32 ; p<0.001\right)$ with higher mean temperature $\left(23.70 \pm 0.17{ }^{\circ} \mathrm{C}\right)$ in open areas compared to under rice canopy areas $\left(22.15 \pm 0.21{ }^{\circ} \mathrm{C}\right)$. Irradiance also differed significantly between micro-environments $\left(F_{1,22}=49.33 ; p<0.001\right)$, with more than double mean values in open areas $(101,104 \pm 7621 \mathrm{~kW})$ than under rice canopy $(41,656 \pm 3681 \mathrm{~kW})$. Chlorophyll fluorescence was significantly higher under rice canopy compared to open areas (Table 1). Photosynthetic pigment concentrations and pigment ratios did not differ between micro-environments (Table 1).

\section{Discussion}

Our study showed that cultivating M. quadrifolia in organic rice farms represents an important opportunity for preserving this endangered species in areas of intensive agriculture. In the two organic farms M. quadrifolia showed better performance than in both the transitional and conventional farms. It is noteworthy that the experiment was performed in a real rice production context, without the possibility to fully standardize the methodology among farms and years. 


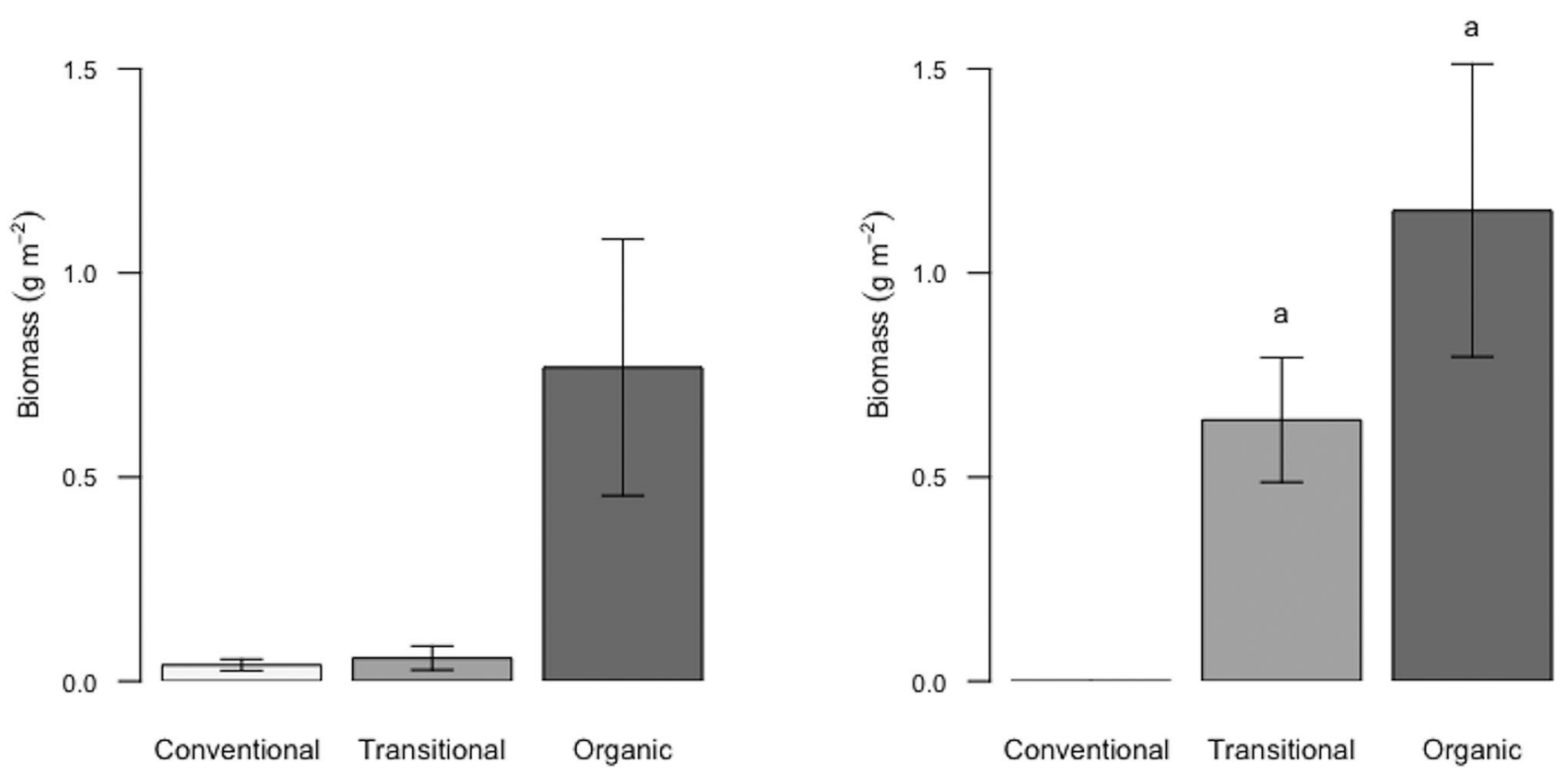

Fig. 1 Mean $(+\mathrm{SE})$ total biomass of $M$. quadrifolia collected from different rice farming systems. Lowercase letters indicate significant $(p<0.05)$ differences between farming systems, according to post hoc Fisher's LSD tests

Fig. 2 Plot scores along the first two axes of stepwise multiple discriminant analysis of water chemistry data (the percentage of variance accounted for by each axis is in parenthesis. Circles: conventional farms. Triangles: transitional farms. Squares: organic farm (the black square indicates the only misclassified case)

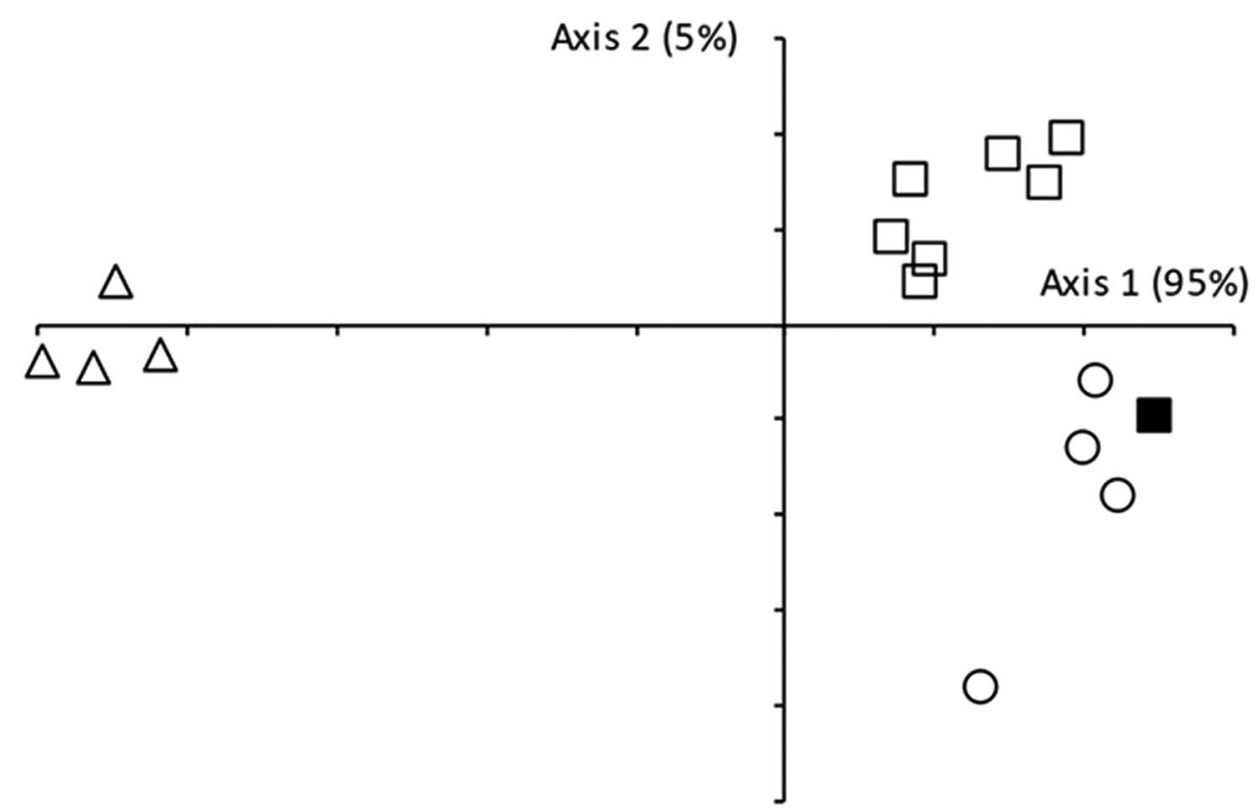

Although this could represent a potential flaw in our experimental design, at the same time it strengthens our conclusions and provide more reliable information than a completely standardized (but far-from-reality) design.

In the conventional farm, $M$. quadrifolia survived herbicide application in 2017 but not in 2018. This was likely due to the effect of the pre-sowing herbicide treatment to which M. quadrifolia was exposed in 2018 but not in
2017. Indeed, the species is sensitive to a broad range of herbicides, but type and strength of the effects vary among them. Aura is considered as the most harmful herbicide, already at 1:100 and 1:1000 dilutions, whereas Clincher One and Viper do not preclude survival of $M$. quadrifolia (Bruni et al. 2013). Glyphosate used in the pre-sowing treatment 2018 should not be as harmful as the abovementioned chemicals (Bruni et al. 2013), but its application in 
Table 1 Mean (+SE) values of chlorophyll fluorescence, concentrations and ratios of photosynthetic pigments in M. quadrifolia leaves from open areas and under rice canopy

\begin{tabular}{lcc}
\hline & Open areas & Under rice canopy \\
\hline Chlorophyll fluorescence & $\mathbf{0 . 6 9} \pm \mathbf{0 . 0 1}$ & $\mathbf{0 . 7 6} \pm \mathbf{0 . 0 1}$ \\
Chlorophyll $\mathrm{a}+\mathrm{b}(\mu \mathrm{g} / \mathrm{g}$ DW) & $17.9 \pm 2.2$ & $20.0 \pm 2.7$ \\
Carotenoids $(\mu \mathrm{g} / \mathrm{g}$ DW) & $4.1 \pm 0.5$ & $3.8 \pm 0.4$ \\
Chlorophyll a / Chlorophyll b & $3.02 \pm 0.05$ & $2.91 \pm 0.03$ \\
Chlorophyll a + b / Carotenoids & $4.67 \pm 0.33$ & $5.01 \pm 0.23$ \\
\hline
\end{tabular}

Bold characters indicate significant differences in one-way ANOVAS $(p<0.01)$

an early development phase (mid-May) may have had a more detrimental effect leading to the die-off of the introduced M. quadrifolia.

Our results demonstrate that $M$. quadrifolia prefers organic rice fields but can also survive in conventional farms with reduced supply of herbicides. Increasing public concern about the use of chemicals in the EU resulted in important Directives like 2009/128/EC —and following updates 2019/782/EC - with the aim to reduce the use of chemicals and to improve their selectiveness (e.g., toward more aggressive weeds; Lamichhane et al. 2016). This could open new interesting opportunities for land sharing between threatened species and farm production. Although we found local differences in the chemical features of the water filling the experimental paddies, mainly due to the distance between farms and to the different management of water supply, effects of these differences on growth of $M$. quadrifolia were overall poor. Previous studies also reported wide ecological amplitude of this species with respect to water chemistry (Bolpagni and Pino 2017). Indeed, M. quadrifolia is a rooted aquatic fern tolerating rather high nutrient levels both in the water and in the soil (Abbasi et al. 2018).

M. quadrifolia exhibited unexpected higher growth potential under rice canopy than in open areas (independently by the used rice cultivar), which suggests that higher $M$. quadrifolia performance is found inside the paddy than in open areas at the edge of a field. Long-term acclimation of vascular plants to light level relies primarily on adjustment of the photosynthetic machinery. Our study revealed poor, if any, capacity of M. quadrifolia to adjust pigment composition to light level. Lower chlorophyll fluorescence values testify that $M$. quadrifolia underwent some degree of stress in full-light habitats. Hence, shadow cast by rice canopy creates a suitable micro-environment for M. quadrifolia. Furthermore, open areas are quickly colonized by exotic invasive weeds like Heteranthera reniformis Ruiz \& Pav., Ammannia coccinea Rottb. and Cyperus microiria Steud. This is an important finding suggesting that a reintroduction of Marsilea quadrifolia in areas of intensive agriculture may have more chances of success if the species is planted under the rice canopy, especially in organic farms (on farm reintroduction).

Since M. quadrifolia is listed in the Directive 92/43/CEE and in the Bern Convention, its conservation is mandatory in the European Union. Consequently, a conservation management plan for this fern is urgent and cannot disregard the agricultural and semi-natural context in which this species grows. Considering that rice fields are recognized worldwide as surrogate habitats for wetland species (Lawler 2001), and many rice farms in the crop district of northwestern Italy are included in protected areas (e.g., the only Special Protection Area "Garzaie della Lomellina" extends for 30.940 ha), such a conservation plan should consider simultaneously the ecological requirements of the species and the needs of stakeholders (i.e., farmers, landowners, local policymakers). We suggest that ad hoc agro-environmental compensations or incentives from the EU Rural Development Plan (RDP) should support farmers willing to reintroduce and maintain M. quadrifolia, at least in organic rice farms. For example, in Lombardy Region (N-Italy) specific funds from the Rural Development Programme (RDP 2014-2020) were available to farmers for maintaining wet meadows listed in Directive 92/43/EC in a 'favorable' conservation status, but also rice fields and wet habitats if relevant for nature conservation. There are of course several open questions related to: (i) level of competition and consequent effects on farm productivity of M. quadrifolia, (ii) interactions between M. quadrifolia and other alien invasive species, (iii) effects on $M$. quadrifolia of frequent crop rotations in organic farms, and (iv) possibility that selective herbicides may allow M. quadrifolia to thrive also in conventional farms. Incentives like those proposed here may benefit several arable species currently threatened or at risk of extinction (Meyer et al. 2013), like Isoëtes malinverniana Ces. \& De Not. and Lindernia procumbens (Krocker) Philcox in our experimental area.

Acknowledgements The authors would like to thank the farmers R. Caimo Duc (Candia Lomellina), E. Bianchi (Torre de Negri), C. Carturan (Candia Lomellina) and A. Paravicini $\dagger$ (Bereguardo) that kindly offered their farms for this experimentation. Thanks are also due to: L. Tomasi, M. Canella, A.W. Rossi, M. Marangon, F. Ferrari, M.C. Mariani and S. Lodetti for their support to field work. We are also grateful to P. Cauzzi (University of Pavia) for Marsilea quadrifolia cultivation in Pavia Botanical Garden. The results of this research will be illustrated as best practices in project CLOVER (Agroecosistemi e Conservazione in Lombardia di specie vegetali rare di Direttiva Habitat), RDP of Lombardy.

Funding Open Access funding provided by Università degli Studi di Pavia. The Grant of Excellence Departments, MIUR-Italy (ARTICOLO 1, COMMI 314 - 337 LEGGE 232/2016), is gratefully acknowledged for the support to one of the authors (Prof. Thomas Abeli).

Open Access This article is licensed under a Creative Commons Attribution 4.0 International License, which permits use, sharing, adaptation, distribution and reproduction in any medium or format, as long 
as you give appropriate credit to the original author(s) and the source, provide a link to the Creative Commons licence, and indicate if changes were made. The images or other third party material in this article are included in the article's Creative Commons licence, unless indicated otherwise in a credit line to the material. If material is not included in the article's Creative Commons licence and your intended use is not permitted by statutory regulation or exceeds the permitted use, you will need to obtain permission directly from the copyright holder. To view a copy of this licence, visit http://creativecommons.org/licenses/by/4.0/.

\section{References}

Abbasi SA, Ponni G, Tauseef SM (2018) Marsilea quadrifolia: a new bioagent for treating wastewater. Water Air Soil Pollut 229(4):133. https://doi.org/10.1007/s11270-018-3743-z

Arbeiter S, Roth T, Helmecke A, Haferland HJ, Tanneberger F, Bellebaum J (2018) Conflict between habitat conservation and Corncrake Crex crex brood protection in managed floodplain meadows. Agric Ecosyst Environ 265:15-21. https://doi.org/10.1016/j. agee.2018.05.030

Bolpagni R, Pino F (2017) Sediment nutrient drivers of the growth dynamics of the rare fern Marsilea quadrifolia. Hydrobiologia 792:303-314. https://doi.org/10.1007/s10750-016-3064-4

Bruni I, Gentili R, De Mattia F, Cortis P, Rossi G, Labra M (2013) A multi-level analysis to evaluate the extinction risk of and conservation strategy for the aquatic fern Marsilea quadrifolia L. in Europe. Aquat Bot 111:35-42. https://doi.org/10.1016/j.aquab ot.2013.08.005

Duru M, Therond O, Martin G, Martin-Clouaire R, Magne MA, Justes E, Journet EP, Aubertot JN, Savary S, Bergez JE, Sartou JP (2015) How to implement biodiversity-based agriculture to enhance ecosystem services: a review. Agron Sustain Dev 35(4):1259-1281. https://doi.org/10.1007/s13593-015-0306-1

EEA (2019) European Environmental Agency. Conservation status and trends of habitat and species. https://www.eea.europa.eu/themes/ biodiversity/state-of-nature-in-the-eu/article-17-national-summa ry-dashboards/conservation-status-and-trends. Accessed 04 Mar 2020

Enterisi (2018) Riso-Evoluzione di mercato e sue prospettive. http:// www.enterisi.it/upload/enterisi/bilanci/RelazioneMIPAFT2018w 15916_1443.pdf. Accessed 12 Dec 2019

Estrelles E, Ibars AM, Morales F, Iranzo J (2001) Recuperación y reintroducción de Marsilea quadrifolia en los arrozales del delta del Ebro (Tarragona, España). Bot Complut 25:251-259

Ferrero A, Vidotto F (2010) History of rice in Europe. In: Sharma SD (ed) Rice. Origin, antiquity and history, 1st edn. Science Publishers, Enfield, pp 341-372

Gentili R, Rossi G, Labra M, Selvaggi A, Gariboldi L, Bedini G, Dallai D, Petraglia A, Alessandrini A, Bonafede F, Villani C, Sgorbati S, Brusoni M (2010) Marsilea quadrifolia L. Inform Bot Ital 42(2):605-609

Hazra KK, Swain DK, Bohra A, Nath CP (2018) Organic rice: potential production strategies, challenges and prospects. Org Agric 8(1):39-56. https://doi.org/10.1007/s13165-016-0172-4
Hill JH, Bayer DE, Bocchi S, Clampett WS (1991) Direct seeded rice in the temperate climates of Australia, Italy and North America. In: IRRI Monograph. International Rice Research Institute, Los Baños, Pilippines pp 91-103

Kraehmer H, Thomas C, Vidotto F (2017) Rice Production in Europe. In: Chauhan B, Jabran K, Mahajan G (eds) Rice Production Worldwide, 1st edn. Springer, USA, pp 93-116

Lamichhane JR, Dachbrodt-Saaydeh S, Kudsk P, Messéan A (2016) Towards a reduced reliance on conventional pesticides in European agriculture. Plant Dis 100(1):10-24. https://doi.org/10.1094/ PDIS-05-15-0574-FE

Lawler SP (2001) Rice fields as temporary wetlands: a review. Isr J Zool 47(4):513-528

Lichtenthaler HK (1987) Chlorophylls and carotenoids: pigments of photosynthetic biomembranes. Methods Enzymol 148:350-382. https://doi.org/10.1016/0076-6879(87)48036-1

Meyer S, Wesche K, Krause B, Leuschner C (2013) Dramatic losses of specialist arable plants in Central Germany since the 1950/60s-a cross-regional analysis. Divers Distrib 19:1175-1187. https://doi. org/10.1111/ddi.12102

Orlando F, Alali S, Vaglia V, Pagliarino E, Bacenetti J, Bocchi S, organic rice network, (2020) Participatory approach for developing knowledge on organic rice farming: management strategies and productive performance. Agric Syst 178:102739. https://doi. org/10.1016/j.agsy.2019.102739

Paracchini ML, Bulgheroni C, Borreani G, Tabacco E, Banterle A, Bertoni D, Rossi G, Parolo G, Origgi R, De Paola C (2015) A diagnostic system to assess sustainability at a farm level: the SOSTARE model. Agric Syst 133:35-53. https://doi.org/10.1016/j. agsy.2014.10.004

Pe'er G, Bonn A, Bruelheide H, Dieker P, Eisenhauer N, Feindt PH, Hagedorn G, Hansjürgens B, Herzon I, Lomba A, Marquard E, Moreira F, Nitsch H, Oppermann R, Perino A, Röder N, Schleyer C, Schindler S, Wolf C, Zinngrebe Y, Lakner S (2020) Action needed for the EU common agricultural policy to address sustainability challenges. People Nat 2(2):305-316. https://doi. org/10.1002/pan3.10080

Rossi G, Orsenigo S, Montagnani C, Fenu G, Gargano D, Peruzzi L, Wagensommer RP, Foggi B, Bacchetta G, Domina G, Conti F, Bartolucci F, Gennai M, Ravera S, Cogoni A, Magrini S, Gentili R, Castello M, Blasi C, Abeli T (2016) Is legal protection sufficient to ensure plant conservation? The Italian red list of policy species as a case study. Oryx 50(3):431-436. https://doi. org/10.1017/S003060531500006X

Viggiani P, Tabacchi M, Angelini R (2003) Vegetazione spontanea di risaie e canali. Bayer Crop Science. L'Informatore Agrario, Verona, Italy

Publisher's Note Springer Nature remains neutral with regard to jurisdictional claims in published maps and institutional affiliations. 